\title{
UPAYA PENCEGAHAN INFEKSI DAN MENJAGA KEBERSIHAN DIRI DENGAN CARA MENCUCI TANGAN YANG BAIK DAN BENAR DI SDN 1 TANJUNG KEMALA
}

\author{
Analia Kunang ${ }^{1}$, Cynthia Puspariny ${ }^{2}$ \\ ${ }^{1}$ Universitas Muhammadiyah Pringsewu(Fakultas Kesehatan) \\ ${ }^{2}$ Universitas Muhammadiyah Pringsewu(Fakultas Kesehatan) \\ Email : analiakunang@umpri.ac.id
}

\begin{abstract}
Abstrak : Upaya Pencegahan Infeksi Dan Menjaga Kebersihan Diri Dengan Cara Mencuci Tangan Yang Baik Dan Benar Di SDN 1 Tanjung Kemala

Anak-anak usia sekolah mempunyai kebiasaan kurang memperhatikan perlunya cuci tangan dalam kehidupan sehari-hari, terutama ketika di lingkungan sekolah. Perilaku tersebut tentunya berpengaruh dan dapat memberikan kontribusi dalam terjadinya penyakit diare. Cuci tangan merupakan tehnik dasar yang paling penting dalam pencegahan dan pengontrolan penularan infeksi. Cuci tangan secara rutin merupakan salah satu upaya yang sangat penting untuk menjaga kebersihan tangan (hand hygiene) dalam upaya pencegahan dan pengendalian infeksi, terutama infeksi nosokomial. Menurut WHO, cuci tangan atau hand wash adalah prosedur membersihkan tangan dengan menggunakan sabun dan air mengalir.Tujuan dari kegiatan ini untuk memberitahu tentang pencegahan infeksi salah satu cara dengan mencuci tangan yang baik dan benar. Metode yang digunakan dengan cara ceramah dan demonstrasi memberi pengetahuan tentang pentingnya mencuci tangan menggunakan sabun.
\end{abstract}

Kata Kunci : Pencegahan infeksi, Cuci tangan

\section{Pendahuluan}

Mencuci tangan merupakan teknik dasar yang paling penting dalam pencegahan dan pengontrolan infeksi. Mencuci tangan merupakan proses pembuangan kotoran dan debu secara mekanis dari kedua belah tangan dengan memakai sabun dan air. Tujuan cuci tangan adalah untuk menghilangkan kotoran dan debu secara mekanis dari permukaan kulit dan mengurangi jumlah mikroorganisme. Diare biasanya kuman ditransmisikan dari tangan yang tidak bersih ke makanan. Kuman-kuman kemudian memapar ke person yang makanan tersebut. Hal ini bisa diegah dengan selalu mencuci tangan setelah menggunakan toilet dan sebelum menyiapkan makanan ( Darmiatun, 2013).

Cuci tangan merupakan cara murah dan efektif dalam pencegahan penyakit menular. Namun hingga saat ini kebiasaaan tersebut seringkali dianggap remeh (Sari, 2011).

Permasalahan perilaku kesehatan pada anak usia Sekolah Dasar biasanya berkaitan dengan kebersihan perorangan, lingkungan dan munculnya berbagai penyakit yang sering menyerang anak usia sekolah, ternyata umumnya berkaitan dengan PHBS (Wowor dkk,2013) . Masalah kesehatan yang terjadi pada anak usia sekolah semakin memperjelas bahwa nilai-nilai PHBS di sekolah masih minimal dan belum mencapai tingkat yang diharapkan.

Untuk itu diperlukan suatu kegiatan intervensi yang dapat meningkatkan pengetahuan, sikap dan tindakan tentang PHBS pada anak sekolah (Lina, 2016).

Hasil (Riskesdas, 2013) menyebutkan bahwa proporsi penduduk umur $>10$ tahun yang berprilaku cuci tangan pakai sabun dengan benar adalah 47\%. Penelitian lain menyebutkan bahwa perilaku sehat seperti mencuci tangan dengan sabun kurang dipromosikan sebagai perilaku pencegahan penyakit dibandingkan promosi obat-obatan flu oleh staff kesehatan 


\section{BAGIMU NEGERI : JURNAL PENGABDIAN MASYARAKAT \\ P-ISSN : 2548-8651 | E-ISSN : 2548-866X \\ Email : ejournal@umpri.ac.id}

(Kemenkes RI, 2014). Anak sekolah merupakan generasi penerus bangsa yang perlu dijaga, ditingkatkan dan dilindungi kesehatannya.

\section{Metode}

Penggunaan metode ceramah dan demonstrasi, memberikan pengetahuan pentingnya pencegahan infeksi dengan cara mencuci tangan dengan benar dan menggunakan sabun. Melakukan pendampingan mencuci tangan pada siswa siswi sekolah dasar. Pada tahapan perencanaan Kegiatan ini dimulai dari dengan melakukan prasurvey tempat untuk pelaksanaan kegiatan, menetapkan sasaran yaitu seluruh siswa siswi SDN 1 Tanjung Kemala. Kemudian melakukan pembuatan proposal dan pengajuan dana $70 \%$ untuk kelancaran proses kegiatan, melakukan penyelesaian perizinan tempat/lokasi yang akan dilakukan kegiatan pengabdian pada masyarakat. Kegiatan ini beranggotakan 6 panitia terdiri dari 2 dosen beserta mahasiswi kebidanan, dan siswa siswi yang mengikuti kegiatan ini berjumlah 26 peserta. Pada kegiatan selanjutnya yang sudah ditentukan waktunya, pada tahap ini pengabdi berkoordinasi dengan Pihak SDN 1 Tanjung Kemala, maka Selanjutnya pengabdi mempersiapkan kegiatan penyuluhan berupa materi tentang Upaya Pencegahan Infeksi Dan Menjaga Kebersihan Diri Dengan Cara Mencuci Tangan Yang Baik Dan Benar dengan media yang digunakan (poster) dan diakhir acara panitia bersama melakukan cuci tangan 6 langkah dengan mengguanakan sabun. Pada tahap pelaksanaan ini diberikan informasi tentang pentingnya pencegahan infeksi dengan cara mencuci tangan menggunakan sabun diberikan materi yang melibatkan semua unsur dalam kegaitan pengabdian masyarakat, kegiatan ini diharapkan bertambahnya pengetahuan para siswa dan siswi tentang pentingnya mencuci tangan. Sehingga dapat diukur setelah kegiatan selesai dengan cara melakukan tanya jawab tentang langkah langakah mencuci tangan yang baik dan benar. 
Email : ejournal@umpri.ac.id

\section{Hasil Dan Pembahasan}

Menjelaskan tentang hasil atau luaran pengabdian bisa berupa peningkatan pengetahuan, keterampilan Pelaksanaan kegiatan ini membutuhkan bantuan dari pihak sekolahan dan siswa siswi yang mau melakukan cuci tangan. kegiatan ini membutuhkan waktu 1 bulan untuk merancang, melaksanakan dan mengevaluasi kegiatan yang dilaksanakan. Beberapa hal yang perlu dibahas dalam hasil pengabdian ini, yaitu motivasi siswa dan siswi untuk melakukan cuci tangan setidaknya sebelum dan sesudah makan. Selanjutnya adalah antusias para peserta setelah mendapatkan materi meningkat, dan mereka berjanji untuk mencuci tangan, mereka menyimak materi dengan baik dengan terjadinya tanya jawab antar penceramah dengan siswa dan siswi. Saat kegiatan berlangsung, ada beberapa kendala seperti siswa dan siswi yang sulit untuk mengikuti kegiatan, namun masalah tersebut dapat diselesaikan dengan mengarahkan siswa siswi tersebut secara perlahan dan membutuhkan proses perhatian yang menarik untuk siswa siswi ikut dalam kegiatan pengabdian masyarakat ini.

Upaya yang dilakukan untuk meningkatkan pengetahuan siswa tentang cuci tangan pakai sabun adalah dengan melakukan penyuluhan dengan metode yang sesuai. Penyuluhan bersifat mengajak dan mengajarkan perlu dilaksanakan pada anak-anak sekolah dasar tentang pentingnya menjaga kebersihan diri sendiri terutama mencuci tangan pakai sabun. Penyuluhan pada dasarnya merupakan proses komunikasi dan proses perubahan perilaku melalui pendidikan, sehingga kegiatan penyuluhan dapat mencapai hasil yang maksimal yang ingin dicapai.

Cuci tangan pakai sabun (CTPS) merupakan tindakan pencegahan terhadap penyakit yang ditularkan melalui tangan, misalnya diare dan infeksi saluran nafas atas. Hasil penelitian menunjukkan bahwa perilaku cuci tangan pada anak SD Di Kabupaten Jember dalam kategori baik sebesar 53,7 \%, sedangkan diare dalam kriteria rendah sebesar 59,3\%. Kondisi ini didukung oleh penelitian Burton, Cobb, Donachie, Judah, Curtis, dan Schmidit (2011) dan Pickering, Boehm, Mwanjali, dan Davis, (2010) menunjukkan bahwa cuci tangan dengan menggunakan sabun lebih efektif dalam memindahkan kuman dibandingkan dengan cuci tangan hanya dengan mengggunakan air. Penelitian ini juga menunjukkan bahwa penyediaan sarana air bersih baik itu di Sekolah Dasar maupun rumah sebagai sarana untuk cuci tangan juga sudah baik. Anak-anak SD sebagaian besar mempunyai kebiasaan cuci tangan menggunakan kran dan kamar mandi. Beberapa hasil riset menunjukkan bahwa promosi perilaku cuci tangan, peningkatan kualitas air bersih dan sanitasi lingkungan telah terbukti mengurangi kejadian penyakit gastrointestinal, penyakit pernafasan dan menurunkan absensi murid pada negara berkembang.

Praktik cuci tangan dipengaruhi oleh sosial ekonomi, tingkat pendidikan dan akses media televisi (Rabbi \& Dey, 2013). Penelitian yang dilakukan oleh Mayasari (2012) juga menunjukkan bahwa terdapat perbedaan tingkat pengetahuan antara anak SD di perkotaan dengan di pedesaan terkait dengan perilaku cuci tangan. Hal ini menunjukkan bahwa akses terhadap media dan informasi sangat penting dalam menunjang keberhasilan promosi cuci tangan menggunakan sabun.

Perilaku hidup sehat yang sederhana seperti mencuci tangan dengan sabun merupakan salah satu cara untuk meningkatkan kesadaran masyarakat tentang pemeliharaan kesehatan pribadi dan pentingnya berperilaku hidup bersih dan sehat. Harapannya dengan cuci tangan yang merupakan kegiatan sepele dan bernilai murah ini apabila dikerjakan secara rutin oleh seluruh masyarakat akan menurunkan berbagai penyakit menular dan meningkatkan status kesehatan masyarakat. 


\section{BAGIMU NEGERI : JURNAL PENGABDIAN MASYARAKAT \\ P-ISSN : 2548-8651 | E-ISSN : 2548-866X \\ Email : ejournal@umpri.ac.id}

\section{Simpulan Dan Saran \\ Simpulan}

Kegiatan ini berbentuk laporan hasil upaya pencegahan infeksi dan menjaga kebersihan diri dengan cara mencuci tangan yang baik dan benar. Keberhasilan ini dapat dilihat dari :

1. Adanya respon yang positif dan antusias para siswa dan siswi terhadap kegiatan ini

2. $90 \%$ peserta mengikuti kegiatan dengan baik dan meningkatkan pengetahuan anak SD tentang upaya pencegahan infeksi dan menjaga kebersihan diri dengan cara mencuci tangan yang baik dan benar

3. Semua siswa dan siswi SDN 1 Tanjung kemala melakukan cuci tangan di air mengalir dan Saran menggunakan sabun

1. Bagi siswa dan siswi

Diharapkan siswa dan siswi melakukan cuci tangan sesering mungkin

2. Pihak sekolah

Diharapkan kepada pihak sekolah untuk lebih meningkatkan upaya promotif kepada siswa dan siswi untuk melakukan penyuluhan tentang PHBS. Untuk itu perlu dilakukan penyuluhan atau pemberian edukasi kepada siswa dan siswi melalui kerja sama dengan stakeholder terkait.

\section{Daftar Rujukan}

Burton, M., Cobb, E., Donachie, P., Judah, G., Curtis, V \& Schmidit, W. (2011). The effect of handwashing with water or soap on bacterial contamination of hands. Int. J. Environ. Res. Public Health, 8 , 97-104. doi:10.3390/ ijerph8010097

Darmiatun. 2013. Pendidikan Karakter di Sekolah. Yogyakarta : Gava Media

Kemenkes RI. 2014. Pedoman Gizi Seimbang. Bina Gizi dan KIA. Jakarta

Lina, H. P. (2016). Perilaku Hidup Bersih dan Sehat (PHBS) Siswa DI SDN 42 Korong Gadang Kecamatan Kuranji Padang. Jurnal Promkes vol 4. no 1, 92-103.

Pickering, A.J., Boehm, A.B., Mwanjali, M \& Davis, J. (2010). Efficacy of waterless hand hygiene compared with handwashing with soap: a field study in Dar es Salaam, Tanzania Am. J. Trop. Med. Hyg., 82(2), 270-278. doi:10.4269/ajtmh.2010.09-0220

Rabbi, E.S \& Dey, N.C. (2013). Exploring the gap between hand washing knowledge and practices in Bangladesh: a cross-sectional comparative study. BMC Public Health, 13:89, 2-7

Riskesdas. (2013). Riset Kesehatan Dasar. Badan Penelitian dan Pengembangan Kesehatan Kementerian Kesehatan RI

WHO. (2009). WHO Guidelines On Hand Hygiene in Health Care. Diakses 1 April 2016, dari https://www.who.int/gpsc/5may/tools/who_guidelines-handhygiene_summary.pdf

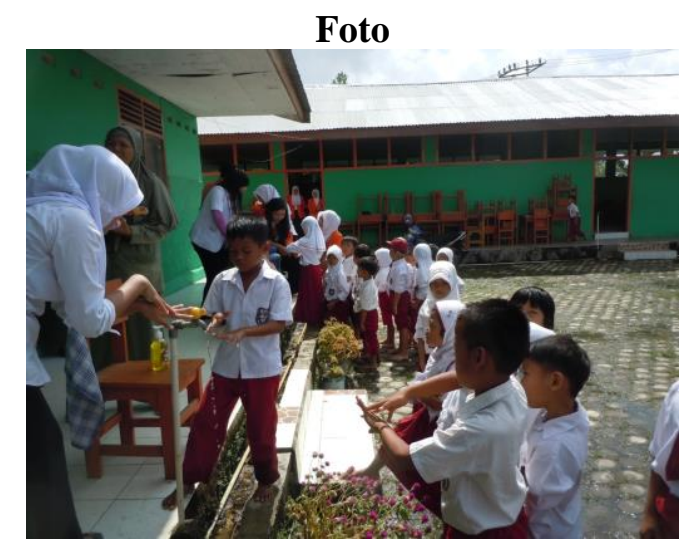

